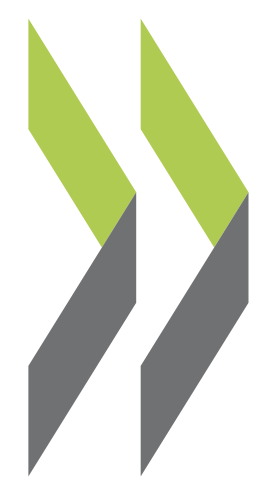

OECD Economics Department Working Papers No. 687

Government Consumption Davide Furceri, Volatility and the Size of Nations 
Organisation de Coopération et de Développement Économiques

Organisation for Economic Co-operation and Development

ECONOMICS DEPARTMENT

English - Or. English

GOVERNMENT CONSUMPTION VOLATILITY AND THE SIZE OF NATIONS

ECONOMICS DEPARTMENT WORKING PAPERS No. 687

By Davide Furceri and Marcos Poplawski Ribeiro

All Economics Department Working Papers are available through OECD's internet web site at ww.oecd.org/working_papers 


\section{ABSTRACT/RÉSUMÉ}

\section{Government consumption volatility and the size of nations}

The aim of this paper is to analyze the relation between the volatility of government consumption and country size. Using a sample of 160 countries from 1960 to 2000 the main findings of our empirical analysis suggest that: 1) smaller countries have more volatile non-discretionary and discretionary government consumption, and also a more volatile government size; 2) the relation between government spending volatility and the size of a country is more negative for more volatile economies; 3 ) the relation between government consumption volatility and country size is more negative for functions of government spending that are characterized by a high level on non-rivality. The results are robust to different time and country samples, different econometric techniques and to several sets of control variables.

JEL Classification: E62, H10

Keywords: Fiscal Policy; Government Size; Fiscal Volatility; Country Size.

******* $*$

\section{La volatilité de la consommation du gouvernement et la taille du pays}

L'objectif de ce papier est d'analyser la relation existant entre la volatilité de la consommation du gouvernement et la taille du pays. Utilisant un échantillon de 160 pays de 1960 à 2000, les principaux résultats de notre analyse suggèrent que : 1) Les petits pays ont une consommation du gouvernement discrétionnaire et non-discrétionnaire plus volatile, de même qu'une taille de gouvernement plus volatile; 2) La relation entre la volatilité des dépenses du gouvernement et la taille du pays est plus négative pour les économies les plus volatiles; 3) La relation entre la volatilité de la consommation du gouvernement et la taille du pays est plus négative for les catégories de dépense publiques qui sont caractérisées par un haut niveau de non-rivalité. Les résultats sont robustes à des changements de période et d'échantillons de pays, à l'utilisation de différentes techniques économétriques et au choix de différentes variables de contrôle

Classification JEL : E62, H10

Mots clés : Politique Budgétaire ; Taille de Gouvernement ; Volatilité Budgétaire ; Taille de Pays

Copyright OECD, 2008

Applications for permission to reproduce or translate all, or part of, this material should be made to: Head of Publications Service, OECD, 2 rue André-Pascal, 75775 Paris Cedex 16, France. 


\section{TABLE OF CONTENTS}

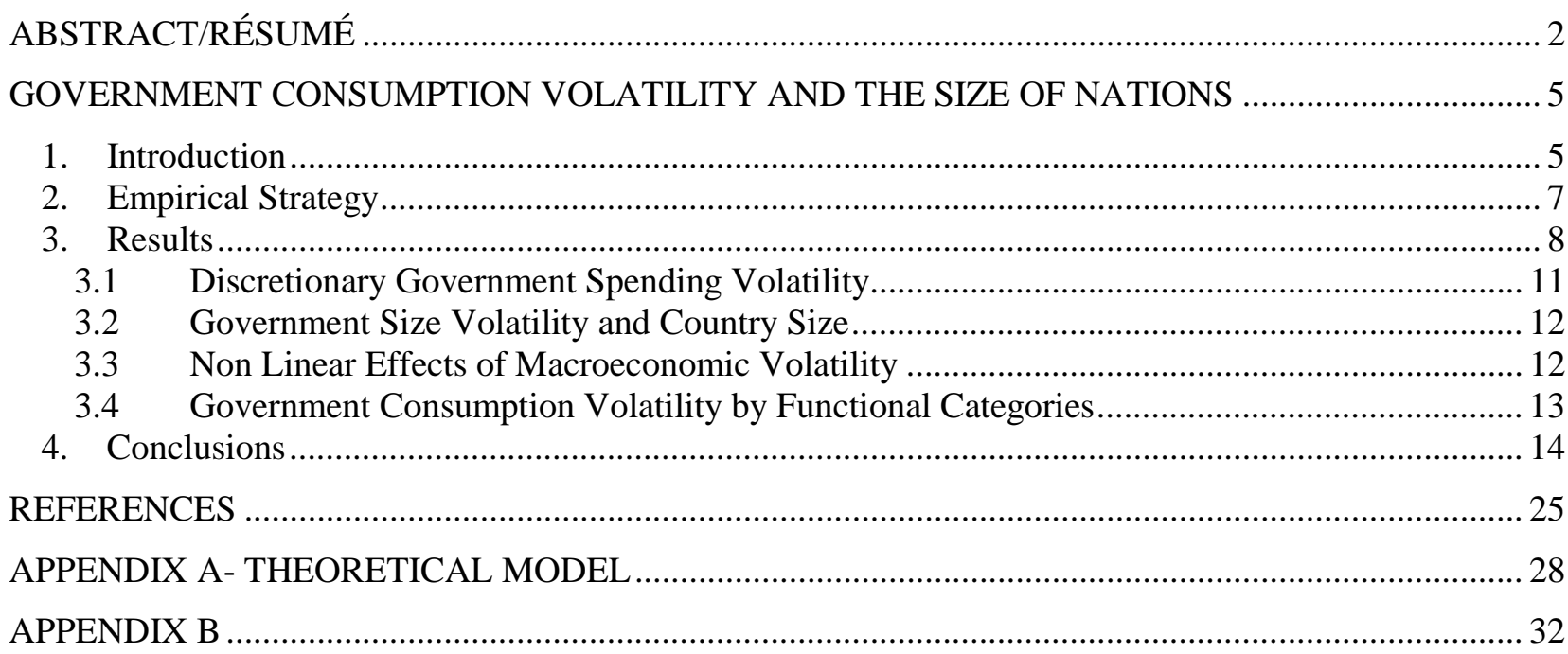

\section{Tables}

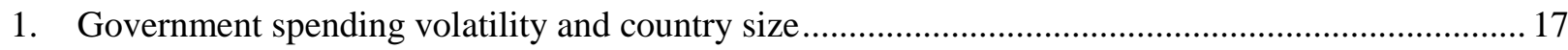

2. Government spending volatility and country size - robustness over time ................................... 18

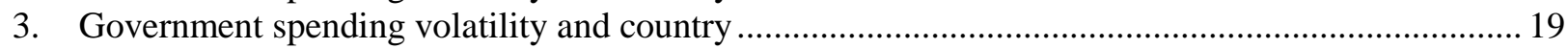

4. Government spending volatility and country size (Country fixed effects) .................................... 19

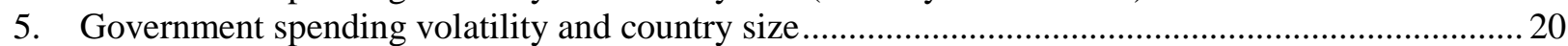

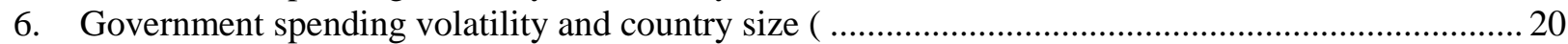

7. Government spending volatility and country size (Rich and poor countries) ................................. 21

8. Discretionary government spending (volatility and country size) ….............................................. 22

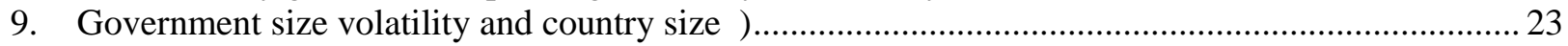

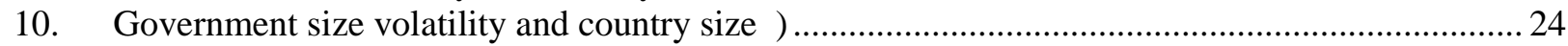

11. Government spending volatility by functional classification and country size ).......................... 24

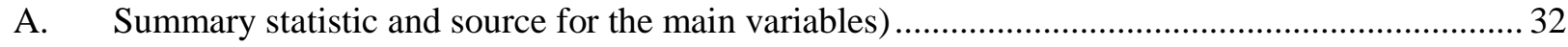

B. Correlation between government consumption volatility categories) …..................................... 33

\section{Figures}

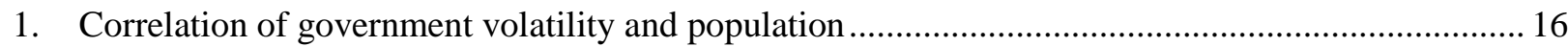


ECO/WKP(2009)28 
ECO/WKP(2009)28

\title{
GOVERNMENT CONSUMPTION VOLATILITY AND THE SIZE OF NATIONS
}

\author{
by \\ Davide Furceri and Marcos Poplawski Ribeiro ${ }^{1}$
}

\section{Introduction}

1. In recent years there has been a growing economic literature concentrating on the effects of scale and country size on various economic outcomes. From a theoretical point of view, the sign of these scale and size effects is ambiguous (Alesina and Spolaore, 2003). Empirically, even though Rose (2006) concludes that countries performance in terms of several indicators is not related with the size of the nation, Alesina and Wacziarg (1998) robustly show that smaller countries have higher levels of public consumption as a share of GDP. ${ }^{2}$ This latter finding originates from economies of scale in the production of public goods and redistributive policies resulting from the higher ability of governments in large countries to spread the cost of financing public goods over a larger pool of taxpayers.

2. Notwithstanding this level effect, to the best of our knowledge, the impact of the size of nations upon the volatility of government spending has not yet been discussed in the literature. From a business cycle perspective, some government spending volatility may be positive if fiscal authorities use expenditures counter cyclically to smooth out the effects of economic shocks.

3. However, most of the existing empirical research in this field finds that higher volatility of public spending impacts negatively on economic growth and welfare (see, among others, Fatás and Mihov, 2003 and 2005; Furceri, 2007; Afonso and Furceri, 2008; and Loayza et al., 2007). Fatás and Mihov (2003), for example, estimate that every percentage point increase in volatility of discretionary fiscal policy lowers economic growth by more than 0.8 percentage points. In turn, Herrera (2007) estimates that the welfare loss of public spending volatility corresponds to $8 \%$ of consumption in developing countries. ${ }^{3}$ Most of

1. We are grateful to Agnès Benassy-Quéré, Jonathan Coppel, Annabelle Mourougane, Ad van Riet, Andy Rose, Martine Carré-Tallon, Jürgen von Hagen and participants at the ECB/DG-E seminar and at $16^{\text {th }}$ Symposium of Public Economics for helpful comments and discussions. We are thankful to Silvia Albrizio for excellent research assistance as well as Catherine Smith for technical assistance. The views expressed in this paper are those of the authors and do not necessarily represent those of the OECD or its member countries. Corresponding author. Mailing address: OECD, 2 rue Andre Pascal, 75775 Paris Cedex 16. Email: Davide.Furceri@oecd.org. Mailing address: CEPII - Centre d'etudes prospectives et d'informations internationales, 9, rue Georges Pitard - 75015, Paris, France. E-mail: marcos.ribeiro@cepii.fr.

2. See, in addition, Bolton and Roland (1997), Alesina and Spolaore (2003), and Alesina et al. (2004).

3. For other analysis on the effects of public spending volatility on the welfare and capital formation of developing countries see Afonso et al. (2006) and Harberger (2005). 
these effects of volatility occur via its negative impact on capital formation and investment as the theories of irreversible investment emphasize (see, in addition, Ramey and Ramey, 1995; Aghion and Banerjee, 2005; and Imbs, 2007).

4. Government spending volatility may be decreasing in the size of nations given that smaller economies are found to be more volatile and exposed to economic shocks (Furceri and Karras, 2007 and 2008). In particular, to the extent that government spending is used for counter-cyclical purposes, smaller economies, characterized by more volatile output and more exposure to idiosyncratic shocks, may use government spending more aggressively. ${ }^{4}$

5. Other effects of country size may work in the opposite direction, though. In larger countries, for instance, more individual heterogeneity may prompt higher political polarization in terms of preferences for type and size of public goods (see, among others, Dixit and Weibull, 2007; Fernández and Levy, 2008; and Lindqvist and Österling, 2008), resulting in larger government spending volatility due to the switching of different political groups in power. ${ }^{5}$

6. The objective of this paper is to analyze the empirical relationship between government consumption volatility and country size using a panel data set that includes 160 countries with observations from 1960 to 2000. That relationship is investigated for both the discretionary (controlling for the automatic stabilizers) and the non-discretionary parts of government consumption.

7. We also estimate the effect of country size on the volatility of the several functional categories of government consumption. In fact, from a theoretical point of view the relation between government spending volatility and country size may be a function of the degree of non-rivality of public goods. In particular, to the extent that public goods are of a non-rival nature, increasing returns to scale of varying government spending may originate from the higher ability to spread the cost of financing it over a larger pool of taxpayers. This promotes less volatile government expenditure in particular if public goods are, as desirable as, or more desired than private consumption.

8. We focus on government consumption rather than on government total spending (or total revenue) given that consumption accounts for most of the spending (approximately $4 / 5$ of the total), and because government total spending is not available for an extensive set of countries for a long time span in our data sample.

9. The main findings of our empirical analysis are: 1) smaller countries have more volatile nondiscretionary and discretionary (corrected for output volatility) government consumption, and also a more volatile government size; 2 ) the relation between government spending volatility and the size of a country is more negative for more volatile economies; 3) although consumption spending in all functional categories is more volatile in smaller countries, the relation between government consumption volatility and country size is more negative for functions of government spending that are characterized by a high

4. Even if output were as volatile as in larger countries, smaller countries would have to use larger fiscal impulses given the smaller size of their fiscal multipliers. Moreover, smaller countries are also less diversified, which again makes them more unstable and asks for more counter cyclical fiscal policy (see Down, 2007).

5. Using the dispersion of self-reported political preferences, Lindqvist and Österling (2008) show that larger nations are more politically polarized, and have governments that both consume and redistribute less. 
level of non-rivality. These results are extremely robust to different time and country samples, different econometric techniques as well as to several sets of control variables. ${ }^{6}$

10. The rest of the paper is organized as follows. Next section describes the empirical methodology used in the paper to test for the relationship between country size and government consumption volatility. Third section reports the results. Finally, Section 4 concludes the paper.

\section{Empirical Strategy}

11. Data for government expenditure is retrieved from the Penn World Table 6.2. The dataset consists of 160 countries, which had available data for each of the years from 1960 to 2000 . We use the log of total population as our measure of country size, and the standard deviation of annual growth of real government consumption spending over the preceding ten years as our measure for government consumption volatility.

12. We set up our estimated models in a number of different ways. In particular, we use (i) OLS both in a bivariate model and in models controlling for a country-specific volatility effect; (ii) Fixed Effects estimation; (iii) Random Effect estimation; and (iv) instrumental variables (IV) estimation both in a bivariate model and in models with control variables.

13. Similarly to Rose's (2006) and Furceri and Karras $(2007,2008)$ strategy, we use four different sets of control variables. ${ }^{8}$

14. The first set of controls includes: (a) the urbanization rate, (b) population density, (c) the log of absolute latitude (kilometres from the equator), (d) a binary dummy variable for a landlocked country, (e) an island-nation dummy, (f) a high income country dummy, (g) regional dummies for developing countries, ${ }^{9}$ and (h) language dummies. ${ }^{10}$ Many of these variables are related to the quality of governments. In fact, as pointed out by La Porta et al. (1998), it is likely that latitude from the equator, income and regional dummies are related to the quality of government and institutions. Moreover, by including

6. In Appendix A we present an extension of the Alesina and Wacziarg (1998) model which illustrates a possible explanation for the negative relation between spending volatility and country size.

7. The choice of the standard deviation of the growth rate of real government consumption over the preceding ten years as measure of consumption volatility could be criticized since, usually, countries with higher growth rates of government spending have higher standard deviations. An alternative measure to control for this "scale" effect could be to consider the coefficient of variation as a measure of volatility. However, there is an obvious problem when we compute the coefficient of variation: for some countries (with highly volatile government consumption) the average growth rate over some time spans turns out to be negative, implying thus a very low measure of volatility in contrast with the evidence. Therefore, we check the robustness of our results with two other measures of government spending. The first is the standard deviation of the cyclical component of real government consumption (Furceri, 2007; Afonso and Furceri, 2008). Its use avoids the "scale" problem since the time average of the cyclical component by construction is zero for each country. The second measure is the ratio between the standard deviation and the average level of real government consumption. Its use avoids business-cycle effects resulting from the employment of annual data. All results of this paper are qualitatively unchanged if we use these measures of volatility.

8. See Appendix B for a more detailed description of the variables and their sources.

9. Dummies are created for developing countries originating from the following regions: 1) Latin America, 2) Sub-Saharan Africa, 3) East Asia, 4) South Asia, 5) Europe-Central Asia, 6) and Middle East-North Africa.

10. Dummies are created for countries speaking the following languages: 1) English, 2) French, 3) German, 4) Dutch, 5) Portuguese, 6) Spanish, 7) Arabic, and 8) Chinese. 
language dummies we are able to capture (at least in part) different level of language fractionalization among and within countries. ${ }^{11}$

15. The second set of control variables augments the first set by including also dummies to control for the effect of new, decolonized, and COMECON countries (see Alesina and Wacziarg, 1998): (a) a dummy for countries created post-World War 2, (b) a dummy for countries created after 1800 but before 1945, (c) a dependency dummy, (d) an OPEC dummy, and (e) a COMECON dummy.

16. The third set of controls includes four other macroeconomic variables that are associated with government consumption volatility: (a) GDP per capita, ${ }^{12}$ (b) Openness ${ }^{13}$ (c) CPI Inflation, and (d) Government size. ${ }^{14}$ In fact, as pointed out by Fatás and Mihov (2003) it is likely that poor countries have shorter and more volatile business cycles due to less developed financial markets, for example, and at the same time they may resort more often to discretionary policy (see also Rand and Tarp, 2002). Similarly, economies with a higher degree of openness, and thus more exposed to external shocks, may use more frequently discretionary counter-cyclical fiscal policies (Rodrik, 1998). In turn, countries with larger government are usually characterized by larger automatic stabilizers and thus are less tempted to use discretionary measures of fiscal policy for fine tuning purposes (Fatás and Mihov, 2001).

17. The main advantage of this set of controls is that they are variables usually associated with government volatility, which are available for all the period under study. Moreover, other variables for which we have data just for the last decade could also be important determinants for government volatility. For this purpose, we consider a fourth set of controls (for which we have data only relatively to the last time period 1991-2000). The variables included are those of the third set of controls plus: (a) an index of the level of Democracy, (b) an index for the level of Corruption, (c) an index for Political Stability, (d) an index for Government Effectiveness, (e) an index for Country Risk, and (f) an index for language fractionalization.

To summarize, we estimate the effect $(\beta)$ of country size on government consumption volatility using the following regression model:

$$
\ln \left(\sigma_{i, t-t+\tau}\right)=\beta \ln \left(P_{o p} p_{\mathrm{it}}\right)+\alpha+\left\{\gamma_{\mathrm{t}} T_{\mathrm{t}}\right\}+\Sigma_{\mathrm{j}} \delta_{\mathrm{j}} X_{\mathrm{ijt}}+\varepsilon_{\mathrm{it}}
$$

where $\sigma$ measures government consumption volatility for country $i$ at time $t$, Pop denotes population, $\left\{T_{\mathrm{t}}\right\}$ denotes a set of time- specific fixed effects, and $\left\{X_{\mathrm{j}}\right\}$ denotes a set of control variables . $\varepsilon$ is a wellbehaved residual, and $\alpha,\{\gamma\},\{\delta\}$, are the coefficients of our other control variables.

\section{Results}

18. Figure 1 provides the scatter plot of government consumption volatility (measured by the standard deviation of the annual growth rate of government consumption expenditure over the preceding ten years) against country size (measured by the natural logarithm of population) for the entire period

11. In the following analysis we will use other variables as a proxy for ethnic fractionalization. The use of language dummies to this purpose, at this stage, is justified for the greater data availability.

12. Although the inclusion of GDP per capita could lead to multicollinearity since both population and GDP per capita may account for scale effects, in our sample these two variables result to be scarcely correlated (0.07).

13. We use as proxy for openness the GDP's share of total exports and imports. Note that this measure is negatively correlated with our measure of country size (0.57). Nevertheless, its inclusion does not change the significance and sign of the coefficient of country size in our regressions, indicating that our estimations are not really affected by the collinearity between the two variables.

14. Government size is here measured as the ratio of government consumption to GDP. 
1960-2000. The figure exhibits a negative and statistically significant relation between these two variables. In particular, the estimate of this simple bivariate relation for the full sample gives us:

$$
\begin{aligned}
\sigma_{\mathrm{i}} & =0.207-0.011 \ln \left(P o p_{\mathrm{i}}\right) \\
& (7.77)(-3.40)
\end{aligned}
$$

with $\mathrm{R}^{2}=0.06$, and $t$ statistics shown in parenthesis. The relationship is clearly negative and statistically significant, even though the relatively low value of the R-squared coefficient suggests that other factors could have a significant impact on volatility of government consumption. ${ }^{15}$ Moreover, the coefficient of country size does not seem to be affected by outliers such as those countries with volatility higher than 0.3 . To confirm this, running again the regression, this time excluding outliers, the relationship is still negative and actually strengthened: ${ }^{16}$

$$
\begin{aligned}
& \sigma_{\mathrm{i}}=0.169-0.008 \ln \left(P o p_{\mathrm{i}}\right) \\
& (9.90)(-3.92)
\end{aligned}
$$

with $\mathrm{R}^{2}=0.08$, and $t$ statistics shown in parenthesis.

19. We now proceed with more formal statistical evidence. Table 1 reports the estimated slope coefficient $(\beta)$ of country size, along with the associated t-statistics in parentheses for several specifications of equation (1). ${ }^{17}$ In particular, the four columns of Table 1 correspond to: (i) bivariate OLS; (ii) OLS including the first set of controls; (iii) OLS including the second set of controls; and (iv) OLS including the third set of controls.

20. Focusing on the full-period (pooled) 1961-2000, it can be readily seen that the relation between country size and government consumption volatility is negative and statistically significant: the larger the size of the country, the less volatile its government expenditure. It is noteworthy that the coefficient on size remains negative and significant in every specification. In particular, two considerations are important. First, the magnitude of the coefficient is broadly constant over the different set of controls. Second, the coefficient remains significant even after controlling for an exhaustive set of regional, geographical, and macroeconomic variables. ${ }^{18}$ In fact, we believe it is significant that country size is shown to reduce

15. Since our dependent variable is based on estimates (sample standard deviation) the regression residuals can be thought of as having two components. The first component is sampling error (the difference between the true value of the dependent variable and its estimated value). The second component is the random shock that would have been obtained even if the dependent variable was directly observed rather than estimated. This would lead to an increase of the standard deviation of the estimates, which will lower the t-statistics. This means that any correction to the presence of this un-measurable error term will increase the significance of our estimates. A second concern is the possibility of heteroskedasticity. However, in most of our estimations heteroskedasticity does not seem to be a problem. When it does, we correct for that by using White standard errors.

16. Estimating a non linear relation, the relation is still significant and negative:

$$
\begin{aligned}
& \sigma_{\mathrm{i}}= 0.169+0.022 \ln \left(P o p_{\mathrm{i}}\right)-0.022 \ln \left(P o p_{\mathrm{i}}\right)^{2} \\
&(9.90)(1.34) \\
&(-1.94)
\end{aligned}
$$

17. Standard errors reported in Table 1 are clustered at country level. Moreover, the language dummies of control set 1 are included in the estimations but not reported in that table.

18. In our estimations, Island, Arabic language (not reported in Table 1), OPEC, and Government Size are other variables that we find to be highly significant. For Island countries that could be attributed to the fact that they are more open to foreign trade, even though expenditure volatility is very high for some of these countries (Le Borgne and Medas, 2007). In turn, Arabic and OPEC economies are rich in oil revenues and 
government spending volatility even when we control for openness, since trade openness is the only variable found to be robustly and significantly related with country size (Rose, 2006). ${ }^{19}$

21. The interpretation of the coefficient relative to country size is the following. By our estimations, an increase of $1 \%$ in population will determine a decrease of $0.2 \%$ in government expenditure volatility (on average). In other words, just because Germany is approximately ten times the size of Belgium, means that Germany has roughly $50 \%$ less volatile government expenditure than Belgium.

22. We have also examined the robustness of the relation between country size and fiscal volatility with respect to different time periods. In particular, we considered four different time samples: 1961-1970, 1971-1980, 1981-1990 and 1991-2000. Table 2 presents, across the above mentioned time periods, the coefficient on country size obtained using the same specification as in Table 1. Our results suggest that while the effect of country size on government consumption volatility remains negative and statistically significant, the magnitude increases over time, especially in the last decade. From a statistical point of view, this could be attributed to a lower number of degrees of freedom for this sample period (for the first sample period), and to the fact that government consumption has been poorly measured during the first years. From an economic point of view, a possible interpretation, as suggested by Alesina and Wacziarg (1998), is that many new decolonized countries had to "build up" their public sector during the first years of our period sample, and as their level and volatility of government consumption converged to a sort of steady state level, the effect of the fundamental determinants of government volatility started to play a larger role.

23. Another robustness check that we provide involves the use of different estimation techniques. Tables 3, 4 and 5 report the estimated slope coefficient of country size for the first, second, and third set of controls with: (i) Fixed Time Effects and Time Random Effects; (ii) Country Fixed Effects and (iii) IV estimation, respectively. ${ }^{20}$ Analyzing these tables we can immediately see that the effect of country size on government volatility is still robust to all methods of estimation. In particular, while the magnitude of the coefficient is broadly unchanged over the different techniques of estimation and set of controls, its significance level increases with respect to OLS and IV when we control for time and country effects both Fixed and Random. ${ }^{21}$

contingent upon that commodity. Hence, the volatility in oil price might explain the higher volatility of government spending on those countries.

19. As a robustness check, we also include private consumption volatility and public debt in the third set of controls of Table 1. The first variable turns out highly significant and positive (not shown here), but country size still remains highly significant when controlling for it. The link between public and household consumption results from the transfers made by the governments or the taxes paid by households (Herrera, 2007; and Herrera and Vincent, 2008). Public debt, in turn, is insignificant in our estimations. Further, its inclusion reduces substantially the number of countries in the sample, which harms the significance of all other variables, including that of country size.

20. As a robustness check we use the logarithm of the country's total area as an instrumental variable for the $\log$ of its population, as did Rose (2006), Furceri and Karras (2007, 2008) and as argued by Drazen (2000). The F-statistic of the simple regression of log of population on log of total area is 2070.43, which suggests that the possible bias of the IV is substantially lower than the one of the OLS (Staiger and Stock, 1997). There is also very little concern of reverse causality. In fact, it is very unlikely that people choose where to live based on consideration of government consumption volatility. In contrast, there could be a more serious issue of endogeneity for other controls variables (such as inflation). We address this issue (and also the one for our variable of interest) considering the starting value of the control between time $t$ and time $t+\tau$, while we use a measure of volatility of time $(t, t+\tau)$.

21. According to the Hausman test, the Fixed Effects specification is preferred to the Random Effects. However, we cannot reject the hypothesis of absence of time effects at the 5\% significant level. Similarly, 
24. The analysis presented so far has shown that the effect of country size on government spending volatility is very robust to different econometric techniques and sets of controls. However, other variables for which we have data only for the last decade, such as Democracy, Corruption, Political Stability, Government Effectiveness, Country risk and language fractionalization, can account for higher fiscal volatility too. To check for robustness, we consider these variables in the OLS and IV estimation. The results are reported in Table 6. Again the results are robust. In particular, while the coefficient on population is still statistically significant its magnitude is increased.

25. It is possible to argue that most of the variation in many determinants of fiscal volatility (such as political constraints, income, inflation, etc.) occurs between the rich and the poor countries. Thus, both from a theoretical perspective and especially from a policy point of view it is important to assess whether the relationship between country size and government spending volatility is still negative within each group (Rich and Poor). ${ }^{22}$ While, we have already shown that our analysis still holds when we include as control variables the level of GDP and income dummies, it would be important also to run two different regressions for each group of countries. Table 7 conveys the results. They show that while the coefficient on population has the same sign across the two different groups, the magnitude and significance level is bigger for poor countries.

\subsection{Discretionary Government Spending Volatility}

26. The results presented so far have provided robust evidence for a negative relation between spending volatility and country size. Similarly relevant, however, is to examine whether smaller countries not only have more volatile total spending, but also more volatile discretionary spending. For this purpose we repeat the analysis conducted so far using a proxy for discretionary consumption volatility, instead of general government consumption volatility, as our dependent variables.

It is important to stress that no consensus exists in the literature on the appropriate measure of discretionary (cyclically adjusted) fiscal policy. ${ }^{23}$ The difficulty mainly comes from the simultaneity in the determination of output and government consumption volatility. For this purpose we use a measure of discretionary fiscal policy that is not affected by output volatility. In more detail, following Fatás and Mihov (2003, 2006), Herrera and Vincent (2008), and Afonso, Agnello and Furceri (2008) our measure is obtained by estimating for each country $i$ the following equation:

$$
\Delta G_{i, t}=\alpha_{i, t}+\beta_{i} \Delta Y_{i, t}+\gamma_{i} \Delta G_{i, t-1}+\delta_{i} W_{i, t}+\varepsilon_{i, t},
$$

where $G$ is the logarithm of real government consumption, $Y$ is the logarithm of real GDP, and $W$ includes a time trend, inflation and inflation squared. The estimated standard deviation of the

the inclusion of country effects does not improve the fitness of our model on the significance of our estimates. This is mainly due to the fact that country effects are to some extent captured by language and regional dummies. However, by including only country effects in the regression with the third set of controls the magnitude of the coefficient of country size increases (to -0.77) and its significance level remains high (t-statistic $=-4.50)$.

22. We use the World Bank classification to differentiate among Rich and Poor countries. In particular, we includes in Poor countries those countries classifies as "Low Income", "Lower Middle Income", and "Upper Middle Income"; and we include in the Rich countries those classifies as "High Income-non OECD" and "High Income-OECD".

23. See Alesina and Perotti (1996), Blanchard (1993) and Fatás and Mihov (2003, 2006) for a detailed discussion on alternative measures of discretionary fiscal policy. 
residuals (i.e. $\left.\sigma_{i, t+\tau}=\sqrt{\operatorname{var}\left(\varepsilon_{i, t-t+\tau}\right)}\right)$ is assumed as a quantitative estimate of discretionary fiscal policy volatility. In order to estimate equation (2) we include the contemporaneous value of output growth and we use past values as instrumental variables to avoid the possibility of endogeneity bias. We instrument current output growth with lagged GDP growth, the index of oil prices, lagged inflation, and the lagged value of government spending growth.

27. Table 8 presents the coefficient on country size obtained using the same specification used in Table 1. Our results show that the effect of country size on discretionary government consumption volatility is still negative and statistically significant, even though significantly smaller in value than that for the general government consumption. ${ }^{24}$ This suggests that part of the higher government consumption volatility in smaller countries can be explained by stronger use of counter-cyclical fiscal policy in those countries.

\subsection{Government Size Volatility and Country Size}

28. The analysis described so far has pointed out that both the level of total spending and its discretionary part are more volatile in smaller economies. This could be mainly driven by the fact that smaller countries have a more volatile output (Furceri and Karras, 2007 and 2008). Thus, it would be interesting to assess whether together with government spending and output, also its ratio is more volatile in smaller economies. For this purpose we replicate our empirical analysis substituting as the dependent variable a measure of government size volatility (i.e. the standard deviation of the growth rate of the ratio between government consumption and GDP over the ten preceding years).

29. Table 9 presents the coefficient on country size obtained using the same specification used in Table 1. Our results point out that the effect of country size on government size volatility is negatively and statistically significant. Moreover, looking at the magnitude of the coefficients and comparing them with those obtained in Table 1, we can see that the effect of country size on government consumption volatility is of the same order of the effect of country size on government size volatility.

\subsection{Non Linear Effects of Macroeconomic Volatility}

30. As discussed before, one of the main factors explaining the negative relation between government spending volatility and country size, it may be the fact that smaller countries are hit more by aggregate shocks than large countries.

A direct way to test this hypothesis is to analyze whether the effect of country size on government spending volatility is a function of the volatility of the economy. For this purpose we estimate the following equation:

$$
\ln \left(\sigma_{i, t-t+\tau}\right)=\beta \ln \left(P o p_{\mathrm{it}}\right)+\xi \mathrm{V}+\phi \ln (\mathrm{Pop})^{*}(\mathrm{~V})+\alpha+\left\{\gamma_{\mathrm{t}} T_{\mathrm{t}}\right\}+\Sigma_{\mathrm{j}} \delta_{\mathrm{j}} X_{\mathrm{ijt}}+\varepsilon_{\mathrm{it}},
$$

where $\mathrm{V}$ is our measure of volatility of the economy given by the standard deviation of the growth rate of aggregate consumption over the ten preceding years. ${ }^{25}$ In particular, given that the effect of country size on

24. For the volatility of discretionary government consumption the coefficient of country size is around 0.07 , whereas for the general government consumption it is around 0.2.

25. Similar results are obtained using aggregate output of investment instead of aggregate consumption. However, assuming that governments use fiscal policy for consumption smoothing and welfare purposes, the choice of this variable may be more appropriate. 
government spending volatility is $\frac{\partial \ln \left(\sigma_{i, t-t+\tau}\right)}{\partial \ln \left(\text { Pop }_{i t}\right)}=\beta+\phi V$, our hypothesis implies that $\beta<O$ and that $\phi<0$.

The relation between country size and government spending volatility is more negative for more volatile economies. Moreover, since more volatile economies may use government spending more aggressively, we should expect a positive sign for the coefficient associated to macroeconomic volatility $\xi$.

31. Table 10 presents the coefficient on country size and the interaction term for three measures of government spending volatility: i) total government consumption volatility, ii) discretionary government consumption volatility, and iii) government size volatility, obtained using the same specification used in Table 1.

32. Our results show that the effect of country size on all measures of spending volatility is still negative and statistically significant. Both total government spending and government size volatility respond positively to macroeconomic volatility, and for both of them our hypothesis that the effect of country size on spending volatility is a function of the volatility of the economy is confirmed.

33. In contrast, our measure of discretionary spending seems to not be affected (both linearly and non-linearly) by macroeconomic volatility, which is plausible given that our measure is taken as the residual part of government spending, which does not respond to economic conditions and to past values of government spending.

34. Summarizing, these results suggest that one of the factors explaining the negative relation between country size and government spending is macroeconomic volatility. However, they also indicate that this factor is not the only one, given that, even in the absence of macroeconomic volatility $(\mathrm{V}=0)$, a negative relation between country size and government spending volatility would persist. This is also confirmed by the fact that the volatility of our discretionary measure of government spending (i.e. not related to economic conditions) is still negatively associated with the size of the country.

\subsection{Government Consumption Volatility by Functional Categories}

35. From a theoretical point of view another factor explaining the negative relation between government spending volatility and country size may be the degree of non-rivality of public goods. In particular, to the extent that public goods are of a non-rival nature, increasing returns to scale of varying government spending may originate from the higher ability to spread the cost of financing it over a larger pool of taxpayers. This promotes less volatile government expenditure in particular if public goods are, as desirable as, or more desired than private consumption.

36. For this purpose, we also estimate the effect of country size on the volatility of the several functional categories of government consumption: i) General public services; ii) Defense; iii) Public order and safety; iv) Economic affairs; v) Housing and community amenities; vi) Health; vii) Recreation, culture and religion; viii) Education; and ix) Social protection. ${ }^{26}$

37. As mentioned above, a larger country size may reduce government consumption volatility because of the higher returns to scale of the non-rival good. To this extent, we should expect expenditure volatility related to non-rival public goods (such as general administration and public order and safety) to be more associated with country size than expenditure volatility related to rival public goods (such as education and health).

\footnotetext{
${ }^{26}$ Data for government consumption classified by function are retrieved from the UN and OECD data sets.
} 
38. However, our preceding empirical analysis has also pointed out that one important factor explaining the relation between country size and government spending volatility is the fact that smaller economies are more subject to economic shocks, thus to the extent that government spending is used for counter-cyclical purposes, we should expect, to a certain extent, all items of government consumption to be negatively associated with country size.

39

Table 11 shows the results of the regression between government consumption volatility classified by economic function and country size for the period 1971-2000 and using the third set of control variables. ${ }^{27}$ Each of the columns of the table corresponds to a different economic function of government consumption.

40. Analyzing the results, we can observe that the relation between government consumption and country size is negative for each of the different categories. Thus, these results seem to confirm the idea that smaller countries tend to have more volatile government consumption also because they are more exposed to idiosyncratic shocks. At the same time, from all government consumption items analyzed, economic affairs and public order which are characterized by a high degree of non-rivality are the ones whose coefficient of country size has larger value.

41. Summarizing, this analysis seems to suggest that due to both higher economies of scale in the provision of non-rival public goods and lower exposure to idiosyncratic shocks, larger economies are more able to stabilize their government consumption.

\section{Conclusions}

42. This paper provides empirical evidence showing that smaller countries tend to have more volatile government consumption spending. The main findings of our empirical analysis are: 1) smaller countries have more volatile discretionary (corrected for output volatility) and non-discretionary government consumption volatility, and a higher government size volatility; 2) the relation between government spending volatility and the size of a country is stronger (more negative) for more volatile economies 3 ) even though consumption spending is more volatile in smaller countries in all functional categories, the relation between government consumption volatility and country size is more negative for functions of government spending that are characterized by a high level of non-rivality. These results are extremely robust to different time and country samples, different econometric techniques as well as to several sets of control variables.

43. Our paper highlights the need for small countries to undertake fiscal adjustments in order to reduce macro-fiscal vulnerabilities and improve their economic growth prospects (see also Le Borgne and Medas, 2007; and Medina Cas and Ota, 2008). In addition, to the extent that large fiscal areas reduce government consumption volatility, our findings reinforce the role of fiscal coordination and the move towards common fiscal policy in monetary unions, even though other factors may undermine and overcome such fiscal manoeuvre (see, among others, Beetsma and Bovenberg, 1998; Beetsma et al., 2001; and von Hagen et al., 2002).

44. The current analysis also offers various possibilities for further research. On the theoretical side, a structural model would be helpful to better understand the mechanisms underlying the economic and political effects of country size on the government spending volatility. For instance, modelling the political side of the economy could be useful to investigate the impacts of country size and political heterogeneity on our variable of interest. On the empirical side, an analysis of the effects of country size on the volatility

\footnotetext{
${ }^{27}$ The results are qualitatively robust also to the inclusion of the additional variables present in the fourth control set.
} 
ECO/WKP(2009)28

of total spending, taxes revenues, and debt management could ratify our findings that that variable indeed acts as an insurance against idiosyncratic shocks, and show how strong this effect is. 
Figure 1. Correlation of government spending volatility and population FIGURE1. CORRELATION OF GOVERNMENT VOLATILITY AND POPULATION

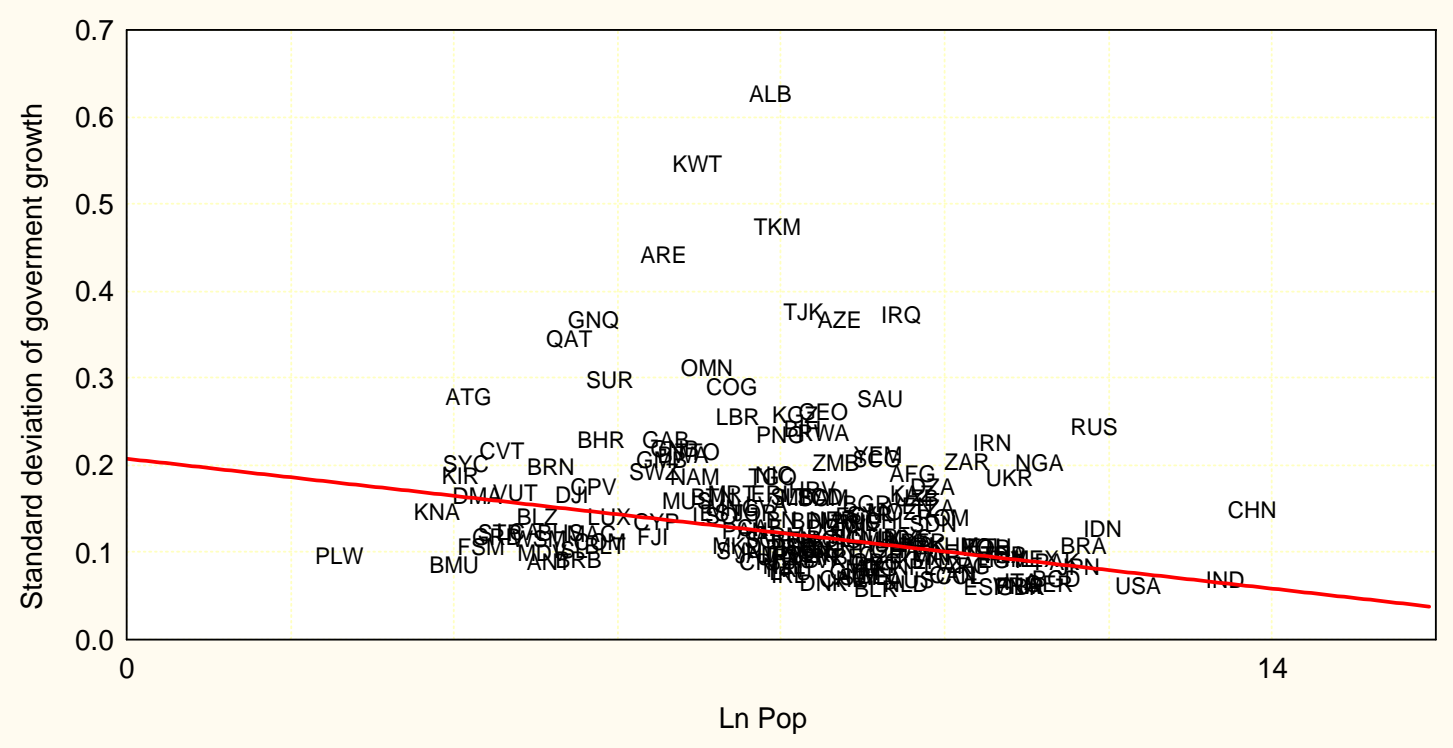


ECO/WKP(2009)28

Table 1. Government spending volatility and country size

\begin{tabular}{|c|c|c|c|c|}
\hline & Bivariate & Control1 & Control2 & Control3 \\
\hline Lnpop & $\begin{array}{c}-0.098 \\
(-4.24)^{* * *}\end{array}$ & $\begin{array}{c}-0.153 \\
(-5.34) * * *\end{array}$ & $\begin{array}{c}-0.160 \\
(-5.00) * * *\end{array}$ & $\begin{array}{c}-0.208 \\
(-4.54) * * *\end{array}$ \\
\hline Urban & - & $\begin{array}{l}-0.002 \\
(-0.53)\end{array}$ & $\begin{array}{l}-0.002 \\
(-0.78)\end{array}$ & $\begin{array}{l}-0.003 \\
(-0.76)\end{array}$ \\
\hline Density & $\begin{array}{l}- \\
-\end{array}$ & $\begin{array}{c}-0.001 \\
(-2.30)^{* *}\end{array}$ & $\begin{array}{l}-0.001 \\
(-0.25)\end{array}$ & $\begin{array}{l}-0.001 \\
(-1.13)\end{array}$ \\
\hline Landlocked & - & $\begin{array}{l}-0.131 \\
(-0.91)\end{array}$ & $\begin{array}{l}-0.071 \\
(-0.48)\end{array}$ & $\begin{array}{l}-0.078 \\
(-0.57)\end{array}$ \\
\hline Island & - & $\begin{array}{c}-0.303 \\
(-2.25)^{* *}\end{array}$ & $\begin{array}{c}-0.238 \\
(-1.74)^{*}\end{array}$ & $\begin{array}{l}-0.223 \\
(-1.55)\end{array}$ \\
\hline $\begin{array}{l}\text { Latitude from } \\
\text { Equator }\end{array}$ & $\begin{array}{l}- \\
-\end{array}$ & $\begin{array}{l}-0.003 \\
(-0.73)\end{array}$ & $\begin{array}{l}-0.004 \\
(-1.57)\end{array}$ & $\begin{array}{c}-0.006 \\
(-2.30)^{* *}\end{array}$ \\
\hline Income & $\begin{array}{l}- \\
-\end{array}$ & $\begin{array}{c}-0.132 \\
(-2.79)^{* * *}\end{array}$ & $\begin{array}{c}-0.124 \\
(-2.37)^{* *}\end{array}$ & $\begin{array}{c}-0.114 \\
(-1.86)^{*}\end{array}$ \\
\hline Opec & $\begin{array}{l}- \\
-\end{array}$ & $\begin{array}{l}- \\
-\end{array}$ & $\begin{array}{c}0.982 \\
(5.05)^{* * *}\end{array}$ & $\begin{array}{c}0.746 \\
(3.85)^{* * *}\end{array}$ \\
\hline Comecon & - & - & $\begin{array}{l}0.212 \\
(0.71)\end{array}$ & $\begin{array}{l}-0.072 \\
(-0.37)\end{array}$ \\
\hline Independence & $\begin{array}{l}- \\
-\end{array}$ & - & $\begin{array}{l}0.000 \\
(0.24)\end{array}$ & $\begin{array}{l}-0.000 \\
(-0.85)\end{array}$ \\
\hline Post war & - & - & $\begin{array}{l}0.085 \\
(0.64)\end{array}$ & $\begin{array}{l}0.063 \\
(0.34)\end{array}$ \\
\hline Inflation & $\begin{array}{l}- \\
-\end{array}$ & - & $\begin{array}{l}- \\
-\end{array}$ & $\begin{array}{l}0.029 \\
(1.19)\end{array}$ \\
\hline Openness & - & - & $\begin{array}{l}- \\
-\end{array}$ & $\begin{array}{l}-0.003 \\
(-0.03)\end{array}$ \\
\hline GDP per capita & - & - & - & $\begin{array}{l}-0.001 \\
(-0.95)\end{array}$ \\
\hline Government Size & $\begin{array}{l}- \\
-\end{array}$ & - & - & $\begin{array}{c}-0.013 \\
(-2.48)^{* *}\end{array}$ \\
\hline $\begin{array}{l}\mathrm{N} \\
\mathrm{R}^{2} \\
\text { Adjusted-R }{ }^{2} \\
\text { Sample Period }\end{array}$ & $\begin{array}{c}545 \\
0.064 \\
0.062 \\
1961-2000\end{array}$ & $\begin{array}{c}438 \\
0.162 \\
0.130 \\
1961-2000\end{array}$ & $\begin{array}{c}376 \\
0.372 \\
0.337 \\
1961-2000\end{array}$ & $\begin{array}{c}275 \\
0.445 \\
0.392 \\
1961-2000\end{array}$ \\
\hline
\end{tabular}

Notes: Regressions estimated by OLS with t-statistics in parenthesis. *,** and ${ }^{* * *}$ correspond to the level of significance at $10 \%, 5 \%$ and $1 \%$ respectively. Standard errors clustered at country level. Language dummies included in the estimations but not reported in Columns "Control 1", "Control 2", and "Control 3". 
Table 2. Government spending volatility and country size - robustness over time

\begin{tabular}{|c|c|c|c|c|}
\hline \multicolumn{5}{|c|}{ 1961-1970 } \\
\hline Lnpop & $\begin{array}{c}\text { Bivariate } \\
-0.096 \\
(-2.26)^{* *}\end{array}$ & $\begin{array}{c}\text { Control1 } \\
-0.109 \\
(-2.25)^{* *}\end{array}$ & $\begin{array}{c}\text { Control2 } \\
-0.081 \\
(-1.67)^{*}\end{array}$ & $\begin{array}{c}\text { Control3 } \\
-0.054 \\
(-0.63)\end{array}$ \\
\hline $\mathrm{N}$ & 94 & 94 & 91 & 66 \\
\hline $\mathrm{R}^{2}$ & 0.052 & 0.315 & 0.385 & 0.472 \\
\hline Adjusted- $\mathrm{R}^{2}$ & 0.042 & 0.183 & 0.215 & 0.227 \\
\hline \multicolumn{5}{|c|}{$1971-1980$} \\
\hline Lnpop & $\begin{array}{c}\text { Bivariate } \\
-0.059 \\
(-1.79)^{*}\end{array}$ & $\begin{array}{c}\text { Control1 } \\
-0.099 \\
(-2.69)^{* * *}\end{array}$ & $\begin{array}{c}\text { Control2 } \\
-0.002 \\
(-2.04)^{* *}\end{array}$ & $\begin{array}{c}\text { Control3 } \\
-0.182 \\
(-2.11)^{* *}\end{array}$ \\
\hline $\mathrm{N}$ & 140 & 137 & 123 & 74 \\
\hline $\mathrm{R}^{2}$ & 0.022 & 0.334 & 0.354 & 0.423 \\
\hline Adjusted- $\mathrm{R}^{2}$ & 0.016 & 0.246 & 0.227 & 0.189 \\
\hline \multicolumn{5}{|c|}{ 1981-1990 } \\
\hline Lnpop & $\begin{array}{c}\text { Bivariate } \\
-0.119 \\
(-4.38)^{* * *}\end{array}$ & $\begin{array}{c}\text { Control1 } \\
0.165 \\
(-4.94)^{* * *}\end{array}$ & $\begin{array}{c}\text { Control2 } \\
-0.149 \\
(-3.71)^{* * *}\end{array}$ & $\begin{array}{c}\text { Control3 } \\
-0.137 \\
(-2.43)^{* *}\end{array}$ \\
\hline $\mathrm{N}$ & 146 & 144 & 126 & 93 \\
\hline $\mathrm{R}^{2}$ & 0.118 & 0.321 & 0.431 & 0.638 \\
\hline Adjusted- $\mathrm{R}^{2}$ & 0.111 & 0.235 & 0.322 & 0.516 \\
\hline \multicolumn{5}{|c|}{$1991-2000$} \\
\hline Lnpop & $\begin{array}{c}\text { Bivariate } \\
-0.108 \\
(-3.42)^{* * *}\end{array}$ & $\begin{array}{c}\text { Control1 } \\
-0.188 \\
(-4.88)^{* * *}\end{array}$ & $\begin{array}{c}\text { Control2 } \\
-0.216 \\
(-4.54)^{* * *}\end{array}$ & $\begin{array}{c}\text { Control3 } \\
-0.221 \\
(-3.51)^{* * *}\end{array}$ \\
\hline $\mathrm{N}$ & 160 & 149 & 124 & 109 \\
\hline $\mathrm{R}^{2}$ & 0.069 & 0.333 & 0.415 & 0.471 \\
\hline Adjusted- $\mathrm{R}^{2}$ & 0.063 & 0.252 & 0.301 & 0.320 \\
\hline
\end{tabular}

Note: Regressions estimated by OLS with t-statistics in parenthesis. ${ }^{* * *}$ and ${ }^{* * *}$ correspond to the level of significance at $10 \%, 5 \%$ and $1 \%$ respectively. Standard errors clustered at country level. Besides Lnpop all other control variables are included in the estimations but not reported in Columns "Control 1", "Control 2", and "Control 3". 
ECO/WKP(2009)28

Table 3. Government Spending Volatility and Country Size

(Time fixed and random effects)

\begin{tabular}{|c|c|c|c|c|}
\hline \multicolumn{5}{|c|}{ 1961-2000 (Time Fixed Effects - FE) } \\
\hline Lnpop & $\begin{array}{c}\text { Bivariate } \\
-0.096 \\
(-5.94) * * *\end{array}$ & $\begin{array}{l}\text { Control1 } \\
-0.149 \\
(-7.22)^{* * *}\end{array}$ & $\begin{array}{c}\text { Control2 } \\
-0.157 \\
(-6.47)^{* * *}\end{array}$ & $\begin{array}{c}\text { Control3 } \\
-0.190 \\
(-5.42)^{* * *}\end{array}$ \\
\hline $\mathrm{N}$ & 545 & 438 & 376 & 275 \\
\hline $\mathrm{R}^{2}$-within & 0.062 & 0.277 & 0.377 & 0.456 \\
\hline $\mathrm{R}^{2}$-between & 0.858 & 0.562 & 0.619 & 0.998 \\
\hline $\mathrm{R}^{2}$-overall & 0.064 & 0.274 & 0.371 & 0.440 \\
\hline \multicolumn{5}{|c|}{ 1961-2000 (Time Random Effects - RE) } \\
\hline Lnpop & $\begin{array}{c}\text { Bivariate } \\
-0.098 \\
(-6.09)^{* * *}\end{array}$ & $\begin{array}{c}\text { Control1 } \\
-0.153 \\
(-7.47)^{* * *}\end{array}$ & $\begin{array}{c}\text { Control2 } \\
-0.160 \\
(-6.53)^{* * *}\end{array}$ & $\begin{array}{c}\text { Control3 } \\
-0.208 \\
(-5.97)^{* * *}\end{array}$ \\
\hline $\mathrm{N}$ & 545 & 438 & 376 & 275 \\
\hline $\mathrm{R}^{2}$-within & 0.062 & 0.276 & 0.375 & 0.452 \\
\hline $\mathrm{R}^{2}$-between & 0.858 & 0.428 & 0.494 & 0.867 \\
\hline $\mathrm{R}^{2}$-overall & 0.064 & 0.275 & 0.372 & 0.445 \\
\hline $\begin{array}{l}\text { Hausman Te } \\
\text { p-value }\end{array}$ & 0.24 & 0.99 & 1.00 & 1.00 \\
\hline
\end{tabular}

Note: Regressions estimated by OLS with t-statistics in parenthesis. ${ }^{*},{ }^{* *}$, and ${ }^{* * *}$ correspond to the level of significance at $10 \%, 5 \%$ and $1 \%$ respectively. Standard errors clustered at country level. Besides Lnpop all other control variables are included in the estimations but not reported in Columns "Control 1", "Control 2", and "Control 3".

Table 4. Government spending volatility and country size (Country fixed effects)

\begin{tabular}{|lcccc|}
\hline \multicolumn{5}{c|}{ 1961-2000 (Country Fixed Effects - FE) } \\
\hline Lnpop & Bivariate & Control1 & Control2 & Control3 \\
& -0.309 & -0.151 & -0.068 & -0.776 \\
$\mathrm{~N}$ & $(-3.32)^{* * *}$ & $(-0.75)$ & $(-0.34)$ & $(-2.74)^{* * *}$ \\
$\mathrm{R}^{2}$ & & & & \\
Adjusted-R & 545 & 438 & 376 & 275 \\
& 0.671 & 0.553 & 0.761 & 0.814 \\
& 0.533 & 0.562 & 0.623 & 0.657 \\
\hline
\end{tabular}

Note: Regressions estimated by OLS with t-statistics in parenthesis. *,**, and ${ }^{* * *}$ correspond to the level of significance at $10 \%, 5 \%$ and $1 \%$ respectively. Standard errors clustered at country level. Besides Lnpop all other control variables are included in the estimations but not reported in Columns "Control 1", "Control 2", and "Control 3". 
Table 5. Government spending volatility and country size (IV)

\begin{tabular}{|lcccc|}
\hline \multicolumn{5}{c}{$1961-2000$} \\
\hline Lnpop & Bivariate & Control1 & Control2 & Control3 \\
& -0.054 & -0.139 & -0.161 & -0.183 \\
& $(-1.91)^{*}$ & $(-4.22)^{* * *}$ & $(-3.99)^{* * *}$ & $(-2.94)^{* * *}$ \\
$\mathrm{~N}$ & & & & \\
$\mathrm{R}^{2}$ & 545 & 438 & 376 & 276 \\
$\mathrm{R}^{2}$-adjusted & 0.051 & 0.274 & 0.372 & 0.304 \\
& 0.049 & 0.246 & 0.337 & 0.242 \\
\hline
\end{tabular}

Note: Regressions estimated by Two Stage Least Squares (TSLS) with t-statistics in parenthesis. *,** and ${ }^{* * *}$ correspond to the level of significance at $10 \%, 5 \%$, and $1 \%$ respectively. Standard errors clustered at country level. Lnpop is here instrumented by the logarithm of the country's total area. All other control variables are included in the estimations but not reported in Columns "Control 1", "Control 2", and "Control 3".

Table 6. Government spending volatility and country size

\begin{tabular}{|lcc|}
\hline & $1991-2000$ & \\
\hline & OLS \& Control4 & IV \& Control4 \\
& -0.200 & -0.138 \\
$\mathrm{~N}$ & $(-2.58)^{* * *}$ & $(-1.23)$ \\
$\mathrm{R}^{2}$ & & 100 \\
$\mathrm{R}^{2}$-adjusted & 100 & 0.499 \\
& 0.503 & 0.291 \\
\hline
\end{tabular}

Note: Regressions estimated by OLS and IV respectively with t-statistics in parenthesis. *** and *** correspond to the level of significance at $10 \%, 5 \%$, and $1 \%$ respectively. Standard errors clustered at country level. Lnpop is here instrumented by the logarithm of the country's total area. All other control variables of control set 4 (Control4) are included in the estimations but not reported in the table. 
Table 7. Government spending volatility and country size (Rich and poor countries)

\begin{tabular}{|c|c|c|c|c|}
\hline \multicolumn{5}{|c|}{ 1961-2000 (Rich Countries) } \\
\hline Lnpop & $\begin{array}{c}\text { Bivariate } \\
-0.159 \\
(-4.83)^{* * *}\end{array}$ & $\begin{array}{c}\text { Control1 } \\
-0.092 \\
(-1.99)^{* *}\end{array}$ & $\begin{array}{c}\text { Control2 } \\
-0.024 \\
(-0.52)\end{array}$ & $\begin{array}{c}\text { Control3 } \\
-0.069 \\
(-1.34)^{*}\end{array}$ \\
\hline $\mathrm{N}$ & 228 & 190 & 166 & 133 \\
\hline $\mathrm{R}^{2}$ & 0.166 & 0.492 & 0.599 & 0.632 \\
\hline $\mathrm{R}^{2}$-adjusted & 0.162 & 0.445 & 0.544 & 0.553 \\
\hline \multicolumn{5}{|c|}{ 1961-2000 (Poor Countries) } \\
\hline Lnpop & $\begin{array}{c}\text { Bivariate } \\
-0.075 \\
(-2.87)^{* * *}\end{array}$ & $\begin{array}{c}\text { Control1 } \\
-0.154 \\
(-3.86)^{* * *}\end{array}$ & $\begin{array}{c}\text { Control2 } \\
-0.202 \\
(-4.69)^{* * *}\end{array}$ & $\begin{array}{c}\text { Control3 } \\
-0.307 \\
(-4.80)^{* * *}\end{array}$ \\
\hline $\mathrm{N}$ & 317 & 248 & 210 & 146 \\
\hline $\mathrm{R}^{2}$ & 0.038 & 0.126 & 0.181 & 0.350 \\
\hline $\mathrm{R}^{2}$-adjusted & 0.035 & 0.070 & 0.099 & 0.231 \\
\hline
\end{tabular}

Note: Regressions estimated by OLS with t-statistics in parenthesis. * ${ }^{* *}$ and ${ }^{* * *}$ correspond to the level of significance at $10 \%, 5 \%$ and $1 \%$ respectively. Standard errors clustered at country level. Besides Lnpop all other control variables are included in the estimations but not reported in Columns "Control 1", "Control 2", and "Control 3". 
Table 8. Discretionary government spending (volatility and country size)

\begin{tabular}{|c|c|c|c|c|}
\hline & Bivariate & Control1 & Control2 & Control3 \\
\hline Lnpop & $\begin{array}{c}-0.075 \\
(-2.44)^{* *}\end{array}$ & $\begin{array}{c}-0.067 \\
(-3.19) * * * \\
\end{array}$ & $\begin{array}{l}-0.029 \\
(-1.43) \\
\end{array}$ & $\begin{array}{c}-0.076 \\
(-3.44) * * * \\
\end{array}$ \\
\hline Urban & $\begin{array}{l}- \\
-\end{array}$ & $\begin{array}{c}0.005 \\
(3.01)^{* * *}\end{array}$ & $\begin{array}{c}0.005 \\
(2.85)^{* *}\end{array}$ & $\begin{array}{c}0.005 \\
(2.61)^{* *}\end{array}$ \\
\hline Density & $\begin{array}{l}- \\
-\end{array}$ & $\begin{array}{l}0.003 \\
(1.42)\end{array}$ & $\begin{array}{c}0.005 \\
(2.39)^{* *}\end{array}$ & $\begin{array}{c}0.006 \\
(3.00)^{* * *}\end{array}$ \\
\hline Landlocked & $\begin{array}{l}- \\
-\end{array}$ & $\begin{array}{c}0.116 \\
(1.88)^{*}\end{array}$ & $\begin{array}{c}0.169 \\
(2.82)^{* * *}\end{array}$ & $\begin{array}{c}0.135 \\
(2.19)^{* *}\end{array}$ \\
\hline Island & $\begin{array}{l}- \\
-\end{array}$ & $\begin{array}{l}0.002 \\
(0.02)\end{array}$ & $\begin{array}{l}0.104 \\
(1.34)\end{array}$ & $\begin{array}{l}-0.002 \\
(-0.02)\end{array}$ \\
\hline $\begin{array}{l}\text { Latitude from } \\
\text { Equator }\end{array}$ & $\begin{array}{l}- \\
-\end{array}$ & $\begin{array}{l}0.000 \\
(0.09)\end{array}$ & $\begin{array}{l}0.000 \\
(0.52)\end{array}$ & $\begin{array}{l}0.001 \\
(0.61)\end{array}$ \\
\hline Income & $\begin{array}{l}- \\
-\end{array}$ & $\begin{array}{c}-0.260 \\
(-8.68)^{* * * *}\end{array}$ & $\begin{array}{c}-0.220 \\
(-8.00)^{* * *}\end{array}$ & $\begin{array}{c}-0.146 \\
(-3.81)^{* * *}\end{array}$ \\
\hline Opec & $\begin{array}{l}- \\
-\end{array}$ & $\begin{array}{l}- \\
-\end{array}$ & $\begin{array}{c}0.148 \\
(1.96)^{*}\end{array}$ & $\begin{array}{c}0.214 \\
(2.76)^{* *}\end{array}$ \\
\hline Independence & - & - & $\begin{array}{c}0.003 \\
(3.93)^{* * * *}\end{array}$ & $\begin{array}{c}0.002 \\
(2.33)^{* * *}\end{array}$ \\
\hline Post war & $\begin{array}{l}- \\
-\end{array}$ & - & $\begin{array}{l}-0.041 \\
(-0.62)\end{array}$ & $\begin{array}{l}-0.103 \\
(-1.43)\end{array}$ \\
\hline Inflation & - & - & - & $\begin{array}{c}0.015 \\
(1.86)^{*}\end{array}$ \\
\hline Openness & $\begin{array}{l}- \\
-\end{array}$ & - & $\begin{array}{l}- \\
-\end{array}$ & $\begin{array}{c}-0.013 \\
(-1.65)^{*}\end{array}$ \\
\hline GDP per capita & - & - & - & $\begin{array}{c}-0.002 \\
(-2.54)^{* *}\end{array}$ \\
\hline $\begin{array}{l}\text { Government } \\
\text { Size }\end{array}$ & - & - & - & $\begin{array}{l}-0.002 \\
(-0.69) \\
\end{array}$ \\
\hline $\mathrm{N}$ & 91 & 90 & 83 & 80 \\
\hline $\mathrm{R}^{2}$ & 0.057 & 0.790 & 0.871 & 0.905 \\
\hline $\begin{array}{l}\text { Adjusted-R }{ }^{2} \\
\text { Sample Period }\end{array}$ & $\begin{array}{c}0.046 \\
1961-2000\end{array}$ & $\begin{array}{c}0.743 \\
1961-2000\end{array}$ & $\begin{array}{c}0.832 \\
1961-2000\end{array}$ & $\begin{array}{c}0.866 \\
1961-2000\end{array}$ \\
\hline
\end{tabular}

Notes: Regressions estimated by Two Stage Least Squares (TSLS) with t-statistics in parenthesis. *,** and *** correspond to the level of significance at $10 \%, 5 \%$, and $1 \%$ respectively. Standard errors clustered at country level. 
ECO/WKP(2009)28

Table 9. Government size volatility and country size

\begin{tabular}{|c|c|c|c|c|}
\hline & Bivariate & Control1 & Control2 & Control3 \\
\hline Lnpop & $\begin{array}{c}-0.091 \\
(-4.29) * * *\end{array}$ & $\begin{array}{c}-0.135 \\
(-6.50)^{* * *}\end{array}$ & $\begin{array}{c}-0.145 \\
(-6.35)^{* * *}\end{array}$ & $\begin{array}{c}-0.204 \\
(-5.35)^{* * *} \\
\end{array}$ \\
\hline Urban & - & $\begin{array}{l}-0.002 \\
(-0.87)\end{array}$ & $\begin{array}{l}-0.001 \\
(-0.51)\end{array}$ & $\begin{array}{l}-0.003 \\
(-0.82)\end{array}$ \\
\hline Density & - & $\begin{array}{l}-0.001 \\
(-1.61)\end{array}$ & $\begin{array}{l}0.000 \\
(0.02)\end{array}$ & $\begin{array}{l}0.000 \\
(0.18)\end{array}$ \\
\hline Landlocked & - & $\begin{array}{l}0.016 \\
(0.14)\end{array}$ & $\begin{array}{l}-0.078 \\
(-0.73)\end{array}$ & $\begin{array}{l}-0.015 \\
(-0.11)\end{array}$ \\
\hline Island & - & $\begin{array}{c}-0.237 \\
(-2.28)^{* *}\end{array}$ & $\begin{array}{c}-0.259 \\
(-2.51)^{* *}\end{array}$ & $\begin{array}{c}-0.237 \\
(-2.00)^{* *}\end{array}$ \\
\hline $\begin{array}{l}\text { Latitude from } \\
\text { Equator }\end{array}$ & - & $\begin{array}{l}-0.003 \\
(-1.17)\end{array}$ & $\begin{array}{c}-0.005 \\
(-2.06)^{* *}\end{array}$ & $\begin{array}{c}-0.007 \\
(-2.29)^{* *}\end{array}$ \\
\hline Income & - & $\begin{array}{c}-0.209 \\
(-5.59)^{* * *}\end{array}$ & $\begin{array}{c}-0.201 \\
(-4.45)^{* *}\end{array}$ & $\begin{array}{c}-0.177 \\
(-3.30)^{* * *}\end{array}$ \\
\hline Opec & - & - & $\begin{array}{c}0.683 \\
(3.78)^{* * *}\end{array}$ & $\begin{array}{c}0.399 \\
(1.95)^{*}\end{array}$ \\
\hline Comecon & - & - & $\begin{array}{l}0.225 \\
(1.05)\end{array}$ & $\begin{array}{l}0.132 \\
(0.86)\end{array}$ \\
\hline Independence & - & - & $\begin{array}{l}0.000 \\
(0.61)\end{array}$ & $\begin{array}{l}-0.000 \\
(-0.85)\end{array}$ \\
\hline Post war & - & - & $\begin{array}{l}0.019 \\
(0.16)\end{array}$ & $\begin{array}{l}0.090 \\
(0.49)\end{array}$ \\
\hline Inflation & - & - & - & $\begin{array}{l}0.006 \\
(0.83)\end{array}$ \\
\hline Openness & - & - & - & $\begin{array}{c}-0.023 \\
(-1.95)^{*}\end{array}$ \\
\hline GDP per capita & - & - & - & $\begin{array}{l}-0.001 \\
(-1.28)\end{array}$ \\
\hline Government Size & $\begin{array}{l}- \\
- \\
\end{array}$ & $\begin{array}{l}- \\
- \\
\end{array}$ & $\begin{array}{l}- \\
- \\
\end{array}$ & $\begin{array}{c}-0.013 \\
(-3.09) * *\end{array}$ \\
\hline $\begin{array}{l}\mathrm{N} \\
\mathrm{R}^{2} \\
\text { Adjusted-R }\end{array}$ & $\begin{array}{c}545 \\
0.041 \\
0.040\end{array}$ & $\begin{array}{c}438 \\
0.275 \\
0.255\end{array}$ & $\begin{array}{c}376 \\
0.399 \\
0.367\end{array}$ & $\begin{array}{c}275 \\
0.548 \\
0.505\end{array}$ \\
\hline
\end{tabular}

Note: Regressions estimated by OLS with t-statistics in parenthesis. *, ${ }^{* \star}$ and ${ }^{* \star *}$ correspond to the level of significance at $10 \%, 5 \%$ and $1 \%$ respectively. Standard errors clustered at country level. Language dummies included in the estimations but not reported in Columns "Control 1", "Control 2", and "Control 3". Government size volatility is defined as the standard deviation of the growth rate of the ratio between government consumption and GDP over the ten preceding years 
Table 10. Government spending volatility and country size

\begin{tabular}{|l|ccc|}
\hline & $\begin{array}{c}\text { Total } \\
\text { Spending }\end{array}$ & $\begin{array}{c}\text { Discretionary } \\
\text { Spending }\end{array}$ & $\begin{array}{c}\text { Government } \\
\text { Size }\end{array}$ \\
\hline Lnpop & -0.113 & -0.110 & -0.065 \\
$(-2.67)^{* * *}$ & $(-3.01)^{* * * *}$ & $(-2.64)^{* * *}$ \\
\hline Consumption & 118.849 & 198.85 & -14.935 \\
volatility & $(1.84)^{*}$ & $(3.53)^{* * *}$ & $(-0.24)$ \\
& & & \\
Interaction & -4.581 & -11.653 & 1.456 \\
& $(-1.17)$ & $(-3.16)^{* * *}$ & $(0.40)$ \\
& & & \\
\hline $\mathrm{N}$ & & & 275 \\
$\mathrm{R}^{2}$ & 275 & 275 & 0.540 \\
Adjusted- $\mathrm{R}^{2}$ & 0.579 & 0.950 & 0.490 \\
\hline
\end{tabular}

Notes: Regressions estimated by OLS with t-statistics in parenthesis. * ${ }^{* *}$ and ${ }^{* * *}$ correspond to the level of significance at $10 \%, 5 \%$ and $1 \%$ respectively. Standard errors clustered at country level. Third set of controls included but not reported.

Table 11. Government spending volatility by functional classification and country size

\begin{tabular}{|lcccccccccc|}
\hline & PU & DE & OS & EA & HO & HE & RE & ED & SP \\
\hline Lnpop & -0.241 & -0.180 & -0.474 & -0.352 & -0.192 & -0.284 & -0.266 & -0.315 & -0.252 \\
& $(-2.46)^{* *}$ & $(-2.13)^{* *}$ & $(4.12)^{* * *}$ & $(-3.99)^{* * *}$ & $(-1.88)^{*}$ & $(-4.03)^{* * *}$ & $(-3.05)^{* * *}$ & $(-4.23)^{* * *}$ & $(-3.51)^{* * * *}$ \\
& & & & & & & & & & \\
$\mathrm{~N}$ & 102 & 83 & 60 & 94 & 95 & 95 & 76 & 100 & 88 \\
$\mathrm{R}^{2}$ & 0.342 & 0.554 & 0.555 & 0.533 & 0.460 & 0.524 & 0.632 & 0.233 & 0.342 \\
$\mathrm{R}^{2}$-adjusted & 0.159 & 0.391 & 0.290 & 0.388 & 0.295 & 0.378 & 0.479 & 0.027 & 0.132 \\
\hline
\end{tabular}

Note: Regressions estimated by OLS with t-statistics in parenthesis. ${ }^{*},{ }^{* *},{ }^{* * *}$ correspond to the level of significance at $10 \%, 5 \%$ and $1 \%$ respectively. Standard errors clustered at country level. Third set of controls included but not reported. PU= General public services; $\mathrm{DE}=$ Defense; $\mathrm{OS}=$ Public order and safety; $\mathrm{EA}=$ Economic affairs; $\mathrm{HO}=$ Housing and community amenities; $\mathrm{HE}=\mathrm{Health}$; $\mathrm{RE}=$ Recreation, culture and religion; $\mathrm{ED}=$ Education; $\mathrm{SP}=$ Social protection. 
ECO/WKP(2009)28

\section{REFERENCES}

Afonso, A., Agnello, L.and D. Furceri, (2008) "Fiscal Policy Responsiveness, Persistence and Discretion." OECD Economics Department Working Papers No. 659.OECD, Paris

Afonso, A.and D. Furceri, (2008). "Government Size, Composition, Volatility and Economic Growth". ECB Working Paper No.849.

Afonso, A., Skuchnecht, L.and V. Tanzi, (2006). "Public sector efficiency: evidence for new EU member states and emerging markets". ECB Working Paper No. 581.

Aghion, P.and A. Banerjee, (2005). Volatility and Growth, Clarendon Lectures in Economics. Oxford University Press, Oxford.

Alesina, A.and R. Perotti, (1996). "Fiscal Expansions and Adjustment in OECD Economies". Economic Policy XXI, , pp.205-240.

Alesina, A., and R Wacziarg, (1998). "Openness, country size and government." Journal of Public Economics 69(3), pp.305-321.

Alesina, A.and E. Spolaore, (2003). The Size of Nations. MIT Press, Cambridge, MA.

Alesina, A., et al. (2003). “Fractionalization”, Journal of Economic Growth 8”, pp.155-194.

Alesina, A., Spolaore, E.and R. Wacziarg., (2004). Trade, growth and the size of countries. In: P. Aghion and S. Durlauf, (Eds.), Handbook of Economic Growth, North-Holland, Amsterdam.

Beetsma, R.and Bovenberg, A.L., 1998. "Monetary Union without Fiscal Coordination May Discipline Policymakers". Journal of International Economics 45, pp.239-258.

Beetsma, R., Debrun, X.and F. Klaassen., (2001). "Is Fiscal Policy Coordination in EMU Desirable?" Swedish Economic Policy Review 8(1), pp.57-98.

Blanchard, O., (1993). Suggestions for a New Set of Fiscal Indicators, in: Verbon, H., and van Winden, F. (Eds.), The New Political Economy of Government Debt, Amsterdam, The Netherlands: Elsevier Science Publishers.

Bolton, P.and G. Roland, 1997. "The breakup of nations A political economy analysis". Quarterly Journal of Economics 112, pp. 1057-1090.

Dixit, A.K.and J.W. Weibull, (2007). "Political polarization. Proceedings of the National Academy of Sciences" 104, pp. 7351-7356.

Down, I., (2007). "Trade Openness, Country Size and Economic Volatility: The Compensation Hypothesis Revisited." Business and Politics, Vol. 9: Iss. 2, Article 3.

Available at: http://www.bepress.com/bap/vol9/iss2/art3

Drazen, A., (2000). Political Economy in Macroeconomics. Princeton University Press, Princeton, NJ. 


\section{ECO/WKP(2009)28}

Fatás, A and I. Mihov, (2003). “The Case for Restricting Fiscal Policy Discretion”. Quarterly Journal of Economics 118, pp.1419-1447.

Fatás, A.and I Mihov, (2005). "Policy volatility, institutions and economic growth." CEPR Discussion Paper 5388.

Fatás, A.and I Mihov, (2006). The Macroeconomics Effects of Fiscal Rules in the US States. Journal of Public Economics 90, pp.101-117.

Fernández, R.and G.Levy, (2008). "Diversity and Redistribution”. Journal of Public Economics 92(5-6), pp.925-943.

Furceri, D., (2007). "Is Government Expenditure Volatility Harmful for Growth? A Cross-Country Analysis”. Fiscal Studies 28 (1),pp. 103-120.

Furceri, D and,G. Karras, (2007). "Country Size and Business Cycle Volatility: Scale Really Matters". Journal of Japanese and International Economies 21(4),pp. 424-434.

Furceri, D and G. Karras, (2008). "Business cycle volatility and country size: evidence for a sample of OECD countries". Economics Bulletin, 5(3),pp. 1-7.

Harberger, A., (2005). On the process of growth and economic policy in developing countries. PPC Issue Paper No. 13. USAID Development Experience Clearinghouse. December.

Herrera, S., (2007). "Public Expenditure and Growth. Policy" Research Working Paper No. 4372, World Bank, October.

Herrera, S and B.Vincent,, (2008). "Public Expenditure and Consumption Volatility. Policy Research" Working Paper No. 4633, World Bank, May.

Imbs, J., (2007). Growth and Volatility. Journal of Monetary Economics 54 (7), pp.1848-1862.

Kaufmann, D., Kraay, A and M. Mastruzzi, (2008). "Governance Matters VII: Aggregate and Individual Governance Indicators, 1996-2007”. World Bank Policy Research Working Paper No. 4654.

La Porta, R et al., (1998). The Quality of Government. Journal of Law, Economics and Organization 15 (1), pp.222-79.

Le Borgne, E., Medas, P., (2007). "Sovereign Wealth Funds in the Pacific Island Countries: Macro-Fiscal Linkages", IMF Working Paper 07/297 (Washington: International Monetary Fund).

Lindqvist, E.and R. Östling, (2008). "Political Polarization and the Size of Government". IFN Working Paper No.749.

Loayza, N. et al. (2007). "Macroeconomic volatility and welfare in developing countries: an introduction". World Bank Economic Review 21, pp. 343-357.

Medina Cas, S.and R.Ota, (2008). "Big Government, High Debt, and Fiscal Adjustment in Small States", IMF Working Paper No.39.

Poplawski Ribeiro, M. and R. Beetsma,, (2008). "The political economy of structural reforms under deficit restrictions". Journal of Macroeconomics 30, pp.179-198. 
Ramey, G.and V.A.. Ramey, (1995). "Cross-country evidence on the link between volatility and growth", American Economic Review, Vol. 85, pp. 1138-51.

Rand, J.and F. Tarp, (2002).” Business Cycles in Developing Countries: Are They Different?" World Development, 30(12), pp. 2071-88.

Rodrik, D., (1998). “Why Do More Open Economies have Bigger Governments?" Journal of Political Economy 106, pp.997-1032.

Rose, A.K., (2006). "Size Really Doesn't Matter: In Search of a National Scale Effect". Journal of the Japanese and International Economies 20 (4), pp. 482-507.

Staiger, D.and J.H. Stock,., 1997. "Instrumental variables regressions with weak instruments". Econometrica 65, pp.557-586.

von Hagen, J et al (2002). "Budgetary consolidation in Europe: quality, economic conditions and persistence". Journal of Japanese and International Economies 16(4), pp.512-535. 


\section{APPENDIX A- THEORETICAL MODEL}

This section presents a simple closed economy model based on Alesina and Wacziarg (1998), which illustrates why smaller countries could have more volatile government consumption. We modify and extend that model in three ways. First, we use a different utility specification, even though our specification provides similar qualitative results as in Alesina and Wacziarg (1998). Second, we allow individual heterogeneity in private consumption, by assuming a different income endowment for each consumer. That assumption introduces idiosyncratic income shocks in our model and it is useful to analyze how a bigger country can mitigate the effects of those shocks. Third, we use a two-period version of the model to compute the volatility of government consumption.

Consider a country composed of $N$ individuals. The Social Planner maximizes the expected sum of utilities of all individuals:

$$
E_{t} \sum_{i=1}^{N} \sum_{t=1}^{2} U_{i, t}=E_{t} \sum_{i=1}^{N} \sum_{t=1}^{2} \beta^{t-1}\left[u\left(c_{i, t}\right)+v\left(G_{t}\right)\right],
$$

where $E_{t}$ is the expectation operator conditional on information at time t, $\beta$ is the social discount factor, $c_{i, t}$ is the private consumption of individual $i$ in period $t$, and $G_{t}$ is the level of non-rival public goods in period $t$. The functions $u$ and $v$ are further assumed to be increasing in $c$ and $G$, strictly concave and twice continuously differentiable.

In each period households are endowed with an income level $y_{i, t}$, on which they have to pay taxes. The resulting net income is assumed to be consumed at the same period, so that the individual household flow budget constraint reads:

$$
c_{i, t} \leq(1-\tau) y_{i, t},
$$

where $\tau$ denotes the constant and exogenous (income) tax rate.

In this society each individual is further assumed to live in a distinct region that faces an idiosyncratic income shock $\varepsilon_{i, t}$. Thus, in each period the stochastic income endowment is given by:

$$
y_{i, t}=\bar{y}+\varepsilon_{i, t},
$$

where $\bar{y}$ is the average income level assumed for simplicity to be constant over time. Moreover, for every period, the income shock $\mathcal{E}_{i, t}$ is independently and identically distributed among the individuals (regions) with expected value equal to zero and standard deviation equal to $\sigma_{\varepsilon}$. Hence, by the Law of Large Numbers, the country's income shock (sum of idiosyncratic shocks) converges to its expected value the larger is the number of individuals in the country.

The government, in turn, raises tax revenues $T_{t}$ and purchases goods $G_{t}$ every period. For simplicity, we also assume that the government does not borrow, which makes the government's flow budget constraint equal to: 


$$
G_{t}=T_{t} \Leftrightarrow G_{t}=\tau \sum_{i=1}^{N} y_{i, t}
$$

Without any further constraints and using (2) and (3), the period-by-period resource constraint in this economy reads:

$$
\sum_{i=1}^{N} y_{i, t}=\sum_{i=1}^{N} c_{i, t}+G_{t} \Leftrightarrow N \bar{y}+\sum_{i=1}^{N} \varepsilon_{i, t}=\sum_{i=1}^{N} c_{i, t}+G_{t}
$$

The Social Planner maximizes then (1) subject to (4) with respect to $c_{i, t}$ and $G_{t}$, which by assuming perfect foresight leads to:

$$
\sum_{i=1}^{N} u^{\prime}\left(c_{i, t}\right)=N v^{\prime}\left(G_{t}\right)
$$

This condition shows that the average marginal utility of consumption is equal to the marginal utility of government consumption when welfare is maximized in this economy. Further, to assess the overall effect of changes in the population size $N$ on government consumption volatility, we resort to the following quadratic utility function (Poplawski Ribeiro and Beetsma, 2008):

$$
u(x)=\frac{v(x)}{\omega}=-(\xi-1) x^{2} / 2+\xi x, \quad \omega>0, \xi>1, \text { and } x<\xi /(\xi-1),
$$

where the restriction $x<\xi /(\xi-1)$ ensures that the marginal utilities of private consumption and public consumption are always positive, and the parameter $\omega$ regulates the desirability of public relative to private consumption. The higher is $\omega$ the more desirable is government expenditure compared to private consumption.

Then, using (6), we obtain from (5) that

$$
G_{t}=\frac{1}{\omega N} \sum_{i=1}^{N} c_{i, t}+\frac{N(\omega-1)}{\omega N} \frac{\xi}{\xi-1},
$$

which by using (4) becomes: ${ }^{28}$

$$
G_{t}=\frac{1}{1+\omega N}\left(N \bar{y}+\sum_{i=1}^{N} \varepsilon_{i, t}\right)+\frac{N(\omega-1)}{1+\omega N} \frac{\xi}{\xi-1} .
$$

Further, from (3) and (7) the effect of country size on the government expenditure over aggregate income (GDP) is:

$$
\frac{\partial\left(G_{t} / Y_{t}\right)}{\partial N}=-\frac{\omega}{(1+\omega N)^{2}}+\frac{\omega-1}{(1+\omega N)^{2}}\left[\frac{\xi}{(\xi-1) Y_{t}}\right]-\frac{N(\omega-1)}{1+\omega N} \frac{\xi}{\xi-1} \frac{\bar{y}}{\left(Y_{t}\right)^{2}}
$$

28. Notice that $\xi$ can always be chosen such that equation (7) provides a larger $G t$ when government expenditure compared to private consumption becomes more desirable (higher $\omega$ ). 
This expression is negative whenever $\omega \geq 1$ and the sum of idiosyncratic shocks $\sum_{i=1}^{N} \varepsilon_{i, t}$ is not too high. ${ }^{29}$ If government consumption is as desirable as, or more desirable than private consumption, then an increase in country size leads to a fall in the government consumption-income ratio.

As Alesina and Wacziarg (1998) discuss, an increase in country size raises the optimal level of public consumption provision, which can be interpreted as an income effect; but it also reduces per capita cost of public goods for a given level of provision, allowing more private consumption (substitution effect). This latter effect comes from the higher ability of the government to spread the cost of financing public goods over a larger pool of taxpayers (higher $N$ ) leading to increasing returns to scale. Therefore, expression (8) shows that if government expenditure is as desirable as private consumption, the substitution effect dominates and the ratio $G_{t} / Y_{t}$ falls when $N$ increases.

In addition, we can easily obtain the variance of government consumption in this simple two-period model. For that, we first compute the average value of that variable:

$$
\bar{G}=\frac{N \bar{y}}{1+\omega N}+\frac{\xi}{\xi-1} \frac{N(\omega-1)}{1+\omega N}+\frac{1}{2(1+\omega N)} \sum_{i=1}^{N}\left(\varepsilon_{i, 1}+\varepsilon_{i, 2}\right),
$$

which makes the variance of government consumption equal to:

$$
\operatorname{var}(G)=\frac{1}{4(1+\omega N)^{2}}\left[\sum_{i=1}^{N}\left(\varepsilon_{i, 1}-\varepsilon_{i, 2}\right)\right]^{2} .
$$

Hence, the effect of an increase in $N$ on the variance of government consumption becomes:

$$
\frac{\partial \operatorname{var}(G)}{\partial N}=-\frac{\omega}{2(1+\omega N)^{3}}\left[\sum_{i=1}^{N}\left(\varepsilon_{i, 1}-\varepsilon_{i, 2}\right)\right]^{2}<0 .
$$

Equation (10) shows that the larger the country size, the lower the variance of government consumption. That is due to two main effects. First, by the Law of Large Numbers, the income shocks $\varepsilon_{i, 1}$ and $\varepsilon_{i, 2}$ converge to their expected values the bigger the country size (higher $N$ ), thus moving that variance towards zero. Intuitively, larger countries are less exposed to specific idiosyncratic shocks, and therefore, government revenues and expenditures become less volatile (see also Rodrik, 1998). Moreover, it is possible to argue that, the larger the country the less exposure to "shock surprises" $\left(\varepsilon_{i, 1}-\varepsilon_{i, 2}\right)$ and the lower the output volatility $\sigma_{\varepsilon}$ (see Furceri and Karras, 2007 and 2008).

Second, an increase in country size eases the provision of a less volatile government expenditure, which is preferred the more desired is the public good compared to private consumption. That is again due to the increasing returns to scale of that non-rival good, and the consequent reduction in the per capita cost of public goods for a given level of provision when $N$ goes up. In fact, as previously argued, if government expenditure is as desirable as, or more desirable than private consumption $(\omega \geq 1)$, then an increase in the country size leads to a fall in government spending-income ratio. Similarly it is possible to see from equation (9) that an increase in the desirability of public over private consumption ( $\omega \uparrow)$ will lead to a decrease in government consumption volatility.

29. More precisely this expression is always negative if $\omega \geq 1$ and $\sum_{i=1}^{N} \varepsilon_{i, t}<\bar{y} \omega \mathrm{N}^{2}$. 
In sum, our model illustrates reasons for less volatile government expenditure in larger countries, namely lower exposure to idiosyncratic risks and economies of scale in public goods provision. Nevertheless, the magnitude and the sign of the effect of country size on the volatility of government consumption remains an empirical question, on which the next sections delve into. 
APPENDIX B

Table A. Summary statistic and source for the main variables

\begin{tabular}{|llccc|}
\hline Description & Source & \# Obs. & Mean & St. Dev. \\
\hline Government Spending & & & & \\
Volatility & PWT6.2 & 451 & 0.015 & 0.017 \\
Log of Population & PWT6.2 & 832 & 14.852 & 2.303 \\
Urbanization Rate & WDI & 819 & 48.842 & 24.839 \\
Density & WDI & 710 & 253.421 & 1300.324 \\
Latitude & Rose & 832 & 9.577 & 15.208 \\
GDP per capita & WDI & 612 & 5220.501 & 7780.298 \\
Openness & WDI & 582 & 76.572 & 45.310 \\
CPI Inflation & WDI & 504 & 55.799 & 499.7929 \\
Democracy & Polity IV & 531 & 3.902 & 4.190 \\
Corruption & KKZ & 184 & -0.004 & 1.001 \\
Political Stability & KKZ & 165 & -0.004 & 1.001 \\
Government & KKZ & 184 & -0.006 & 1.000 \\
Effectiveness & ICRG & 139 & 67.937 & 11.743 \\
Country Risk & & & & .0280 \\
Language & ADEKV & 191 & 0.394 & \\
Fractionalization & & &
\end{tabular}

Note: PWT6.2 refers to the Penn World Table v. 6.2. Rose refers to A.K. Rose's website.

ADEKV= Alesina et al. (2003); WDI=World Bank Development Indicators; KKZ= Kaufmann et al. (2008). 
Table B. Correlation between government consumption volatility categories

\begin{tabular}{|c|c|c|c|c|c|c|c|c|c|c|}
\hline & GS & PU & $\mathrm{DE}$ & OS & EA & $\mathrm{HO}$ & $\mathrm{HE}$ & RE & ED & SP \\
\hline GS & 1 & & & & & & & & & \\
\hline PU & 0.215 & 1 & & & & & & & & \\
\hline DE & 0.164 & 0.044 & 1 & & & & & & & \\
\hline OS & 0.173 & 0.591 & 0.092 & 1 & & & & & & \\
\hline EA & 0.440 & 0.320 & 0.249 & 0.561 & 1 & & & & & \\
\hline $\mathrm{HO}$ & 0.088 & 0.207 & 0.078 & 0.255 & 0.341 & 1 & & & & \\
\hline $\mathrm{HE}$ & 0.026 & 0.397 & 0.162 & 0.753 & 0.423 & 0.21 & 1 & & & \\
\hline $\mathrm{RE}$ & -0.045 & 0.044 & 0.192 & 0.177 & 0.266 & 0.30 & 0.394 & 1 & & \\
\hline ED & 0.088 & 0.234 & 0.073 & 0.610 & 0.565 & 0.16 & 0.696 & 0.128 & 1 & \\
\hline SP & 0.076 & 0.141 & 0.082 & 0.375 & 0.322 & 0.32 & 0.531 & 0.715 & 0.416 & 1 \\
\hline
\end{tabular}

$\mathrm{GS}=$ Government Spending; $\mathrm{PU}=$ General public services; $\mathrm{DE}=$ Defense; $\mathrm{OS}=$ Public order and safety; $\mathrm{EA}=$ Economic affairs; $\mathrm{HO}=$ Housing and community amenities; $\mathrm{HE}=\mathrm{Health}$; $\mathrm{RE}=\mathrm{Recreation}$, culture and religion; $\mathrm{ED}=$ Education; $\mathrm{SP}=$ Social protection. 


\section{WORKING PAPERS}

The full series of Economics Department Working Papers can be consulted at www.oecd.org/eco/working_papers/

686. Infrastructure investment: links to growth and the role of public policies (March 2009) Balázs Égert and Tomasz Kozluk and Douglas Sutherland

685. Infrastructure and growth: empirical evidence (March 2009) Balázs Égert and Tomasz Kozluk and Douglas Sutherland

684. The effects of population structure on employment and productivity (March 2009) Hervé Boulhol

683. The macroeconomic consequences of banking crises in OECD countries (March 2009) David Haugh, Patrice Ollivaud and David Turner

682. Adjusting housing policies in Slovakia in light of euro adoption (March 2009) Felix Hüfner

681. Achieving fiscal flexibility and safeguarding sustainabilit - The case of Slovakia (March 2009) Isabell Koske

680. Raising the flexibility of the Slovak economy during the catch-up phaseDo Latin American central bankers behave non-linearly? The experience of Brazil, Chile, Colombia and Mexico (March 2009) Isabell Koske

679. Do Latin American central bankers behave non-linearly? The experience of Brazil, Chile, Colombia and Mexico

(February 2009) Luiz de Mello, Diego Moccero and Matteo Mogliani

678. Enhancing educational performance in Australia (February 2009) Vassiliki Koutsogeorgopoulou

677. Quantifying the effect of financial conditions in the euro area, Japan, United Kingdom and United States (February 2009) Stéphanie Guichard, David Haugh et David Turner

676. Taking stock of existing structural policy and outcome indicators/ Un inventaire des indicateurs structurels de politique et de performance (February 2009) Davide Furceri and Annabelle Mourougane

675. Stabilization Effects of Social Spending: Empirical Evidence from a Panel of OECD Countries (February 2009) Davide Furceri

674. Fiscal Convergence, Business Cycle Volatility and Growth (February 2009) Davide Furceri

673. Boosting Productivity in Korea's service sector (February 2009) Randall S. Jones 
672. Sustaining growth in Korea by reforming the labour market and improving the education system (February 2009) Randall S. Jones and Masahiko Tsutsumi

671. Reforming the tax system to promote economic growth and cope with rapid population ageing (February 2009) Randall S. Jones

670. Financial market stability: Enhancing regulation and supervision (February 2009) Jeremy Lawson, Sebastian Barnes and Marte Sollie

669. Overcoming the financial crisis (February 2009) Andrea De Michelis

668. Financial crises: past lessons and policy implications (February 2009) Davide Furceri and Annabelle Mourougane

667. Reforms to open sheltered sectors to competition in Switzerland (February 2009) Andrés Fuentes

666. Raising education outcomes in Spain (February 2009) Andrés Fuentes

665. Health care reform in the United States (February 2009) David Carey, Bradley Herring and Patrick Lenain

664. The role of $R \& D$ and technology diffusion in climate change mitigation: new perspectives using the WITCH model (February 2009) Valentina Bosetti, Carlo Carraro, Romain Duval, Alessandra Sgobbi and Massimo Tavoni

663. Long-run GDP growth framework and scenarios for the world economy (January 2009) Romain Duval and Christine de la Maisonneuve

662. Realising South Africa's employment potential (January 2009) Geoff Barnard

661. Making the most of Norwegian schools (January 2009) Romina Boarini

660. Can the financial sector continue to be the main growth engine in Luxembourg? (January 2009) Arnaud Bourgain, Patrice Pieretti and Jens Høj

659. Fiscal policy responsiveness, persistence, and discretion (December 2008) António Afonso, Luca Agnello, Davide Furceri

658. The economics of climate change mitigation: policies and options for the future (December 2008) Jean-Marc Burniaux, Jean Chateau, Romain Duval and Stéphanie Jamet

657. Maximising Mexico's gains from integration in the world economy (December 2008) David Haugh, Roselyne Jamin and Bruno Rocha 